\title{
Pembuatan Sistem Informasi Wisata "Go-Selotapak" Berbasis Android
}

\author{
Billion Prasetya ${ }^{1}$, Endah Asmawati $^{2 *}$, Dhiani Tresna Absari ${ }^{3}$ \\ ${ }^{1}$ Jurusan Teknik Informatika, Fakultas Teknik, Universitas Surabaya, Surabaya-Indonesia \\ * corresponding author: endah@staff.ubaya.ac.id
}

Abstract-Selotapak Village is one of the tourist villages in Trawas. Selotapak Village develops tourism based on natural potential and community empowerment. Therefore, tourist sites are scattered in almost all parts of the village. One of the most well-known locations to the public is the Wangan Tengah Terraces. Other tourist locations are still rarely visited by tourists because they are not well known and their locations are spread out. Each tourist location has its own characteristics, for example Watu Tapak is the site of the founding of Selotapak village. To be able to introduce all tourism in Selotapak village to the public, a tourist information system is needed. The Go-Selotapak application is a information system that was created to be able to provide information about tourist location, maps, tourist descriptions, tour manager contacts (rental guides and vehicles), facilities and infrastructure. Data collection methods were carried out through interviews with village managers and government as well as distributing questionnaires to tourists. The data obtained were analyzed to find out the system requirements. System implementation is done using Android Studio (Java), Laravel, and Hostinger. Trials were carried out on tourism managers and tourists. The validation results show that $100 \%$ of the respondents from tourism managers stated that the tourism information system that was created was able to show all tourist sites in Selotapak Village along with their complete descriptions. More than $80 \%$ of tourist respondents stated that this application makes it easy to find out the tours in Selotapak and get to the location. In general, with this tourism information system, the public can easily find out all the tourist locations scattered in Selotapak village and with the 'get direction' feature, tourists will find it easy to go to tourist sites.

Keywords: go-selotapak, tourism information system, selotapak

Abstrak-Desa Selotapak merupakan salah satu desa wisata di Kecamatan Trawas. Wisata yang dikembangkan berbasis potensi alam dan pemberdayaan masyarakat. Oleh sebab itu lokasi wisata tersebar hampir di seluruh bagian desa. Satu lokasi yang paling dikenal masyarakat adalah Terassering Wangan Tengah. Lokasi wisata yang lain masih jarang dikunjungi wisatawan karena belum dikenal dan lokasinya menyebar. Setiap lokasi wisata mempunyai ciri khas tersendiri, misalkan Watu Tapak merupakan situs berdirinya desa Selotapak. Untuk dapat mengenalkan semua wisata yang ada di desa Selotapak ke masyarakat luas, diperlukan sebuah sistem informasi wisata. Aplikasi Go-Selotapak adalah system informasi wisata desa Selotapak yang dibuat untuk dapat memberikan informasi tentang peta lokasi wisata, deskripsi wisata, kontak pengelola wisata (sewa pemandu dan kendaraan), serta sarana dan prasarana. Metode pengumpulan data dilakukan melalui wawancara ke pihak pengelola dan pemerintahan desa serta menyebarkan kuesioner ke wisatawan. Data yang diperoleh dianalisis untuk mengetahui kebutuhan sistem. Implementasi sistem dilakukan dengan menggunakan Android Studio (Java), Laravel, dan Hostinger. Ujicoba dilakukan ke pengelola wisata dan wisatawan. Hasil validasi menunjukkan $100 \%$ responden pengelola wisata menyatakan bahwa system informasi wisata yang dibuat sudah bisa menunjukkan semua lokasi wisata di Desa Selotapak beserta deskripsinya secara lengkap. Lebih dari $80 \%$ responden wisatawan menyatakan bahwa aplikasi ini memudahkan dalam mengetahui wisata-wisata yang ada di Selotapak dan menuju lokasi. Secara umum, dengan adanya system informasi wisata ini masyarakat dengan mudah mengetahui semua lokasi wisata yang tersebar di desa Selotapak dan dengan adanya fitur 'get direction' wisatawan mendapatkan kemudahan untuk menuju lokasi wisata.

Kata kunci: go-selotapak, sistem informasi wisata, selotapak

\section{PENDAHULUAN}

Desa Selotapak berlokasikan di Kecamatan Trawas, Kabupaten Mojokerto. Saat ini di desa Selotapak terdapat enam lokasi sebagai destinasi wisata, dimana letak tiap destinasi agak berjauhan. Keenam lokasi tersebut adalah pusat informasi wisata, Terassering Wangan Tengah, Sumber Ubalan, Watu tapak, area ATV, dan Sumber Towo. Setiap sudut desa mempunyai keunikan tersendiri, sehingga dengan konsep wisata berbasis wisata alam pegunungan dan pemberdayaan masyarakat, maka jumlah lokasi wisatanya akan terus bertambah. Pusat informasi wisata berada di sekitar Balai Desa Selotapak. Di sini pengunjung dapat menikmati budaya lokal dengan cara menggunakan baju daerah adat Jawa. Dengan memakai baju daerah Jawa tersebut, wisatawan dapat berfoto dengan latar belakang Gunung Penanggungan, sawah, dan rumah bernuansa desa. Di Terassering Wangan Tengah, wisatawan dapat menikmati keindahan sawah terasering dan Gunung Penanggungan. Sumber Ubalan merupakan wisata di perbukitan yang menyatukan persawahan, sumber air, kolam, taman 
bunga dan tempat berfoto. Sedangkan Watu Tapak merupakan wisata situs berdirinya desa Selotapak (Asmawati, dkk, 2020). Tersebarnya lokasi wisata dan beberapa tempat lokasinya agak jauh dari jalan utama desa (misal Sumber Towo, Watu Tapak, dan area ATV) membuat wisatawan tidak mengetahui lokasi tersebut. Hasil survei ke 25 wisatawan yang datang ke Terasering Wangah tengah menunjukkan bahwa semua wisatawan belum mengetahui adanya Watu Tapak dan Sumber Towo. Jadi diperlukan suatu media untuk mengenalkan semua lokasi wisata desa Selotapak ke wisatawan.

Penelitian ini bertujuan membuat sebuah aplikasi yang berupa sistem informasi wisata desa Selotapak. Aplikasi diberi nama Go-Selotapak yang berarti ajakan pergi ke Selotapak. Melalui aplikasi ini pengelola wisata dapat dengan mudah menyebarkan informasi wisata yang ada di Selotapak beserta lokasi dan deskripsinya. Apabila ada wisata yang baru, pihak pengelola dapat menambahkan wisata tersebut di aplikasi. Bagi wisatawan, aplikasi GoSelotapak dapat memberi kemudahan untuk mengetahui lokasi wisata dan informasi tentang wisata tersebut, sehingga wisatawan dapat menentukan lokasi mana yang ingin dikunjungi (Lengkong, 2019; Duwitau, 2020). Selain itu, dengan aplikasi ini wisatawan dijamin antitersesat saat menuju suatu lokasi wisata, karena pada aplikasi dilengkapi dengan fitur 'get direction'.

Penelitian sistem informasi wisata yang mendukung penelitian ini antara lain penelitian yang dilakukan Musdar (2020). Sistem yang dibuat berupa prototype yang memuat beberapa tempat wisata di propinsi Sulawesi Selatan. Sistem berbasis mobile ini mampu menyajikan informasi pariwisata seperti destinasi wisata, wisata kuliner, event, dan foto objek pariwisata. Sistem dapat menyajikan informasi pariwisata yang mencakup 110 informasi destinasi, 39 informasi event, 45 informasi kuliner, dan foto objek wisata dari 12 kabupaten kota. Hasil pengujian menunjukkan bahwa fitur pada sistem dapat berfungsi dengan baik dan berhasil menampilkan informasi pariwisata yang sesuai.

Sedangkan Latifah (2021) melakukan penelitian tentang rancang bangun sistem informasi pariwisata sebagai media promosi di Kabupaten Lampung Barat. Penelitian menggunakan pemodelan analisis sistem berbasis objek, yaitu use case diagram, class diagram dan diagram aktivitas. Data-data yang digunakan dalam pembuatan system informasi pariwisata meliputi data komentar, data pariwisata, akomodasi, galeri, dan pesan. Sistem terdiri dari dua akun, yaitu admin dan pengunjung. Informasi yang ditampilkan system meliputi berita atau informasi terbaru Dinas Pemuda dan Olahraga Kabupaten Lampung Barat Bidang Pariwisata, profil, galeri, obyek wisata di Kabupaten Lampung barat, dan beberapa informasi pariwisata lainnya.

Beberapa fitur yang ada pada dua penelitian di atas digunakan sebagai salah satu dasar dalam membangun system. Pada penelitian ini, sistem yang dibuat Musdar (2020) mempunyai karakteristik yang sama dengan system yang akan dibuat. Sistem ini memuat beberapa tempat wisata dan dapat menampilkan informasi dan foto objek wisata. Pada penelitian ini akan ditambahkan beberapa fitur, yaitu fitur komentar dan rating, sewa pemandu atau kendaraan, dan get direction. Tambahan fitur diperoleh dari analisis kebutuhan sistem yang telah dilakukan. Sedangkan penelitian Latifah (2021) lebih untuk menampilkan data secara statis. Sistem yang dibuat pada penelitian ini bisa digunakan langsung oleh wisatawan saat berwisata di Selotapak dengan fitur-fitur yang mudah digunakan.

Penelitian ini dilakukan sebagai langkah awal untuk lebih mengenalkan lokasi wisata di desa Selotapak. Pengembangan pemberdayaan masyarakat dalam mengelola wisata bisa menjadi faktor yag mempercepat pengembangan wisata desa Selotapak. Melalui aplikasi yang dibuat, pihak pengelola tetap dapat menambahkan informasi wisata baru ke dalam aplikasi, sehingga wisatawan dapat dengan cepat mengetahui informasi terbaru yang diupload pengelola wisata. 


\section{METODE}

Penelitian dilakukan melalui beberapa tahapan, sebagai berikut.

1. Pengumpulan data. Tahapan awal dengan mengumpulkan data mengenai faktor-faktor apa menjadi akar permasalahan belum dikenalnya lokasi wisata di Selotapak. Pengumpulan data dilakukan dengan menyebarkan kuesioner kepada wisatawan yang datang ke Terassering Wangah Tengah. Kuesioner disebarkan secara offline dengan menggunalan metode purposive yang dikombinasi dengan metode simple random sampling. Kuesioner direspons oleh 25 wisatawan. Terdapat $72 \%$ responden yang hanya mengetahui Terassering Wangah Tengah sebagai destinasi wisata Selotapak, sedangkan sisanya mengetahui pusat informasi wisata dan atau sumber ubalan. Bahkan tiga lokasi lainnya tidak diketahui oleh semua responden. Secara lengkap hasil survei dapat dilihat pada Tabel 1. Selain itu juga ditanyakan perihal informasi yang ingin diketahui responden terkait tempat wisata. Beberapa informasi yang diinginkan adalah lokasi dan deskripsi tempat tersebut, waktu terbaik berkunjung ke tempat tersebut, jalan menuju lokasi, review wisatawan, dan foto-foto

Tabel 1

Pengetahuan Wisatawan Tentang Wisata Selotapak

\begin{tabular}{clcc}
\hline No & \multicolumn{1}{c}{ Lokasi yang diketahui } & Frek & \% \\
\hline 1 & Terassering Wangah Tengah & 18 & 72 \\
2 & Terassering Wangah Tengah, Pusat Informasi Wisata & 4 & 16 \\
3 & $\begin{array}{l}\text { Terassering Wangah Tengah, Pusat Informasi Wisata, } \\
\text { Sumber Ubalan }\end{array}$ & 2 & 8 \\
4 & Terassering Wangah Tengah, Sumber Ubalan & 1 & 4 \\
\hline & Jumlah & 25 & 100 \\
\hline
\end{tabular}

Selain survei ke wisatawan, pengambilan data juga dilakukan dengan mewawancarai pemerintahan desa (kepala desa) dan seorang pengelola wisata (kelompok sadar wisata). Kedua responden berpendapat bahwa salah satu penyebab banyaknya wisatawan yang tidak mengetahui lokasi-lokasi wisata adalah kurangnya informasi terkait lokasi tersebut. Tidak ada papan petunjuk ke lokasi. Tidak banyak informasi di media sosial untuk lokasi wisata yang belum dikenal masyarakat.

2. Analisis kebutuhan system. Berdasarkan hasil kuesioner dan wawancara, maka dibangun sebuah sistem untuk membantu wisatawan mendapatkan informasi wisata desa Selotapak. Sistem ini mempunyai fitur sesuai dengan hasil analisis dari data kuesioner dan wawancara. Terdapat akun admin yang dapat menambah/edit/hapus berita, fitur atau foto, serta membuat destinasi baru. Sedangkan wisatawan dapat melihat semua yang diupload admin, memberi komentar dan rating untuk setiap lokasi wisata.

3. Desain dan implementasi sistem. Sistem dibangun dengan menggunakan Android Studio (Java), Laravel, dan Hostinger.

4. Uji coba sistem. Untuk menguji akurasi dari sistem yang dibangun maka dilakukan dua macam uji coba, yaitu uji coba secara internal dan uji coba secara eksternal. Uji coba internal dilakukan dengan dua macam skenario. Setiap skenario menggunakan inputan lokasi yang berbeda. Hasil dari uji coba internal dikaji oleh peneliti dan pengelola wisata. Setelah sistem lolos dari ujicoba internal, selanjutnya dilakukan uji coba eksternal. Uji coba eksternal dilakukan dengan meminta 30 responden mencoba sistem yang telah dibangun. Responden adalah wisatawan yang berkunjung ke Selotapak. Pemilihan 
responden dilakukan secara purpose simple random sampling. Masukan responden dari hasil ujicoba akan digunakan untuk menyempurnakan system.

5. Hasil (kesimpulan dan saran)

Hasil yang diperoleh dirangkum dalam bentuk kesimpulan. Masukan-masukan dari berbagai pihak akan menjadi saran untuk pengembangan sistem.

HASIL

Sistem yang dibangun berupa aplikasi mobile dan diberi nama Go-Selotapak, yang berarti ajakan untuk pergi berwisata ke Selotapak. Aplikasi ini dibuat berdasarkan hasil analisis dari kuesioner yang diberikan ke wisatawan dan pihak pengelola/pemerintahan desa. Terdapat dua macam pengguna yang dapat menggunakan aplikasi, yaitu wisatawan dan admin. Untuk dapat menggunakan aplikasi ini, apabila hanya ingin melihat, menggunakan menu tertentu dan berkomentar atau memberi rating, wisatawan tidak perlu registrasi, cukup mengunduh aplikasi saja. Namun apabila wisatawan ingin melakukan pemesanan atau menggunggah foto maka wisatawan harus login terlebih dahulu. Admin dapat menambahkan/edit/hapus lokasi wisata beserta informasinya yang meliputi nama lokasi, titik lokasi, deskripsi singkat, foto, kontak pengelola wisata, sarana dan prasarana.

Pada pengguna/wisatawan, pada halaman awal, aplikasi akan menampilkan wisata, profil desa, layanan jasa, dan keluar. Untuk wisatawan yang mempunyai akun, terdapat dua fitur yang disamarkan dan belum bisa digunakan, yaitu riwayat transaksi dan update profil. Kedua fitur ini akan dikembangkan untuk penelitian lebih lanjut. Apabila pengguna memilih fitur wisata, maka akan ditampilkan peta desa Selotapak beserta lokasi wisata dan pusat pemerintahan desa. Jika dipilih salah satu lokasi wisata, maka akan ditampilkan deskripsi wisata tersebut beserta foto, informasi penting (misalkan jam buka/tutup, waktu terbaik berada di lokasi) dan sarana prasarana. Apabila dipilih profil desa maka akan dimunculkan identitas desa Selotapak, yang meliputi alamat, nama kepala desa, uraian singkat desa serta tautan foto kegiatan desa dan tempat wisata.

Pada aplikasi ini, untuk yang mempunyai akun, juga tersedia layanan jasa, yaitu persewaan pemandu wisata dan kendaraan (sepeda/sepeda motor). Menu sewa kendaraan akan muncul jika sebelumnya pengguna menyewa pemandu wisata terlebih dahulu. Pada setiap fitur, pengguna dapat memberikan rating dan komentar. Tampilan sistem dapat dilihat pada Gambar 1.
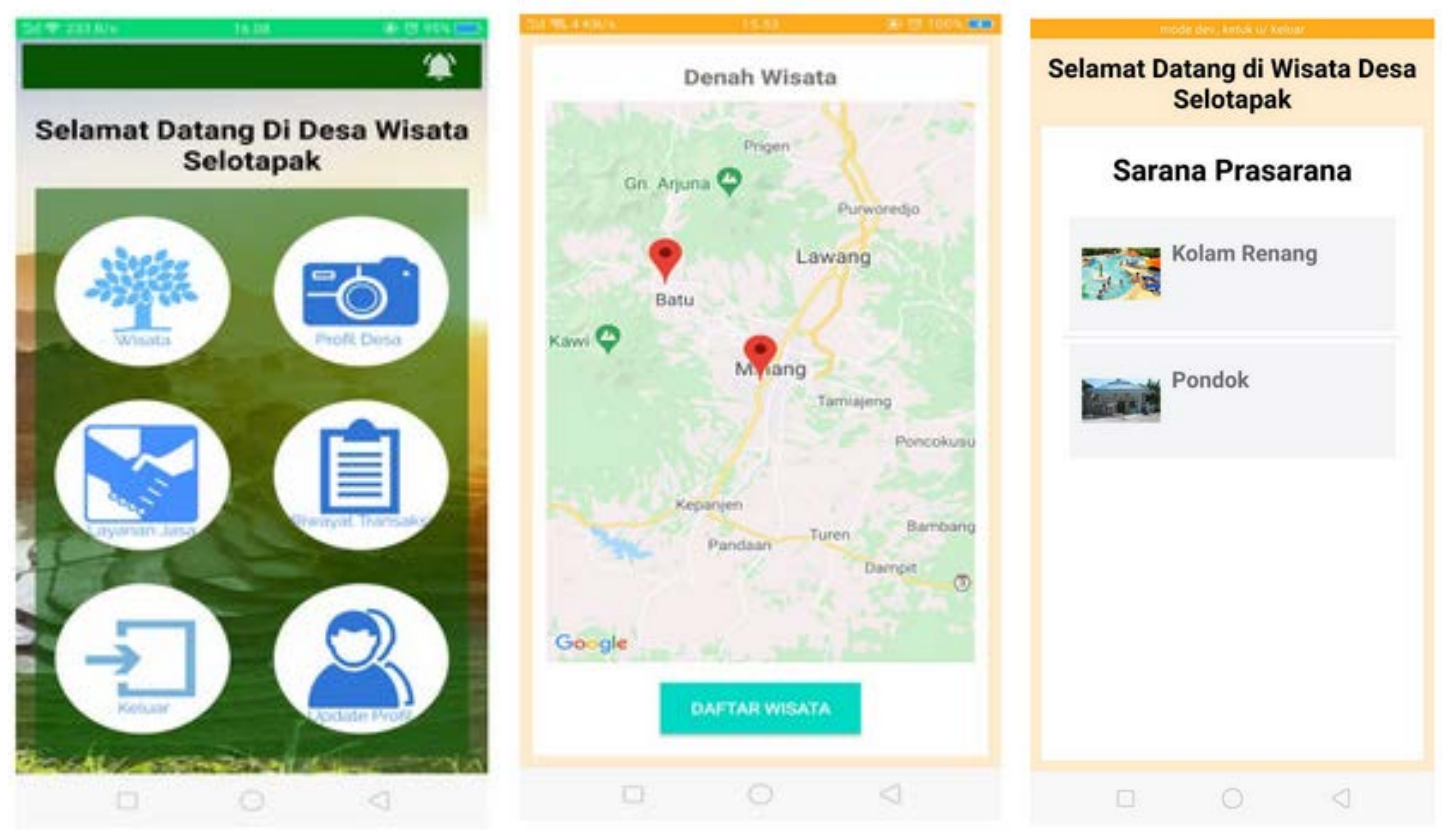

Gambar 1. Tampilan aplikasi go-selotapak. 
Akurasi dari sistem Go-Selotapak dinilai melalui uji coba internal dan uji coba eksternal. Uji coba internal dilakukan melalui dua tahap, yaitu uji coba untuk melihat bahwa aplikasi sudah bebas dari error dan ujicoba untuk melihat akurasi dari sistem. Ujicoba akurasi dilakukan oleh seorang yang benar-benar mengetahui kondisi wisata Selotapak. Pada penelitian ini, akurasi sistem divalidasi oleh ketua pengelola wisata. Uji coba internal tahap satu dimulai dengan membuat dua destinasi wisata baru pada sistem, yaitu Watu Tapak dan Sumber Towo. Kemudian semua fitur yang ada di aplikasi dicoba. Kemudian hasil uji coba internal tahap satu divalidasi oleh ketua pengelola wisata untuk melihat keakuratannya. Hasil uji coba internal dapat dilihat pada Tabel 2.

Tabel 2

Hasil Ujicoba Internal

\begin{tabular}{clcc}
\hline \multirow{2}{*}{ No } & \multicolumn{1}{c}{ Fitur } & \multicolumn{2}{c}{ Lokasi Wisata } \\
\cline { 3 - 4 } & & Watu Tapak & Sumber Towo \\
\hline 1 & Tambah/edit/hapus lokasi & Berhasil & Berhasil \\
2 & Tambah/edit/hapus titik lokasi & Berhasil & Berhasil \\
3 & Tambah/edit/hapus deskripsi & Berhasil & Berhasil \\
4 & Upload/hapus foto & Berhasil & Berhasil \\
5 & Tambah/edit/hapus kontak pengelola & Berhasil & Berhasil \\
6 & Tambah/edit/hapus sarana prasarana & Berhasil & Berhasil \\
7 & Tambah/edit/hapus daftar pemandu & Berhasil & Berhasil \\
& wisata & & Berhasil \\
8 & Tambah/edit/hapus kendaraan & Berhasil & Berhasil \\
9 & Tambah/edit/hapus profil desa & Berhasil & Berhasil, namun titik akhir \\
10 & Ketepatan fitur get direction & Berhasil & masih sedikit berbeda \\
& & & dengan lokasi sebenarnya \\
\hline
\end{tabular}

Selanjutnya dilakukan uji coba eksternal. Uji coba eksternal dilakukan kepada 30 wisatawan yang datang ke Selotapak. Sebanyak 40\% wisatawan dari Mojokerto, 50\% dari Surabaya/Sidoarjo, dan 10\% dari beberapa daerah di Indonesia (Jakarta, Banyuwangi). Berdasarkan tujuan wisata, $30 \%$ responden adalah pecinta fotografi, dan sisanya merupakan keluarga atau rombongan yang ingin menikmati keindahan alam Selotapak. Pada semua responden, pertama kali peneliti mendemonstrasikan fitur dan cara kerja Go-Selotapak. Setelah itu responden diberi kesempatan untuk mencoba aplikasi Go-Selotapak secara mandiri. Selesai mencoba aplikasi Go-Selotapak, setiap responden diminta untuk mengisi kuesioner. Kuesioner dibuat dalam skala Likert 1 sampai 4; skala 1 menyatakan sangat tidak setuju, 2 tidak setuju, 3 setuju, dan 4 sangat tidak setuju. Berdasarkan hasil kuesioner, diperoleh data sebagai berikut.

- Pendapat wisatawan terkait informasi tempat wisata yang ada di peta lokasi aplikasi, sebanyak $37 \%$ responden menyatakan setuju dan $60 \%$ responden menyatakan sangat setuju bahwa peta lokasi bisa memberikan infomasi tempat wisata di Selotapak.

- $33 \%$ responden setuju dan $67 \%$ responden sangat setuju bahwa deskripsi wisata di aplikasi dapat memudahkan wisatawan untuk mendapatkan gambaran lokasi wisata tersebut.

- Selain itu, $33 \%$ responden setuju dan $67 \%$ responden sangat setuju bahwa foto-foto di aplikasi dapat membantu wisatawan untuk pengenalan awal lokasi. Foto-foto juga membuat wisatawan berkeinginan untuk mengunjungi lokasi tersebut.

- Mengenai fitur get direction, $60 \%$ responden setuju dan $40 \%$ responden sangat setuju tentang fitur ini dapat mengarahkan wisatawan ke lokasi yang dimaksud. 
- $33 \%$ responden setuju dan $67 \%$ responden sangat setuju bahwa review dan rating lokasi wisata dapat digunakan dengan baik.

- Untuk fitur sewa pemandu dan kendaraan, sebanyak $50 \%$ setuju dan $33 \%$ sangat setuju terkait kebermanfaatan fitur.

- Dan sebanyak $33 \%$ responden setuju dan $67 \%$ responden sangat setuju bahwa aplikasi mudah digunakan.

Beberapa uraian responden terkait fitur di aplikasi antara lain sebagai berikut.

- Fitur sewa pemandu dan kendaraan diharapkan menjadi fitur yang terpisah. Saat ini, wisatawan yang hendak menyewa kendaraan harus menyewa pemandu wisata terlebih dahulu. Padahal, menurut responden, peta lokasi dan fitur get direction sudah membantu untuk mendapatkan lokasi wisata, namun mereka memerlukan kendaraan (sepeda/sepeda motor) untuk menuju lokasi tersebut. Jadi wisatawan memerlukan sewa kendaraan tapi tidak memerlukan pemandu wisata.

- Diperlukan informasi terkait foto yang bisa diupload di aplikasi.

- Beberapa fitur yang belum berfungsi (saat ini tampak di aplikasi namun tidak dapat diklik) sebaiknya dihilangkan dulu.

Pengujian sistem secara eksternal juga dilakukan ke responden dari pemerintah desa dan pengelola wisata. Langkah pengujian dilakukan dengan mendemonstrasikan fitur dan cara kerja Go-Selotapak terlebih dahulu, kemudian responden diberi kesempatan untuk mencoba aplikasi Go-Selotapak secara mandiri. Kedua responden menyatakan bahwa penambahkan wisata baru dapat dilakukan dengan mudah. Demikian juga dalam menambahkan deskripsi, mengedit nama pemandu, jenis atau nomor kendaraan, dan mengunggah foto. Secara umum sistem informasi wisata yang dibuat sudah bisa menunjukkan semua lokasi wisata di Desa Selotapak beserta deskripsinya secara lengkap.

\section{BAHASAN}

Aplikasi Go-Selotapak mempunyai fitur sesuai dengan yang dibutuhkan untuk menyelesaikan permasalahan, yaitu mengenalkan lokasi wisata di Desa Selotapak ke masyarakat umum. Fitur-fitur yang dibuat sudah melalui pengujian secara internal dan eksternal. Berdasarkan hasil uji coba internal, diperoleh bahwa semua fitur sudah berjalan sesuai dengan fungsinya. Namun ketepatan fitur get direction masih belum sempurna. Fitur belum berhasil mendeteksi lokasi Sumber Towo sampai di lokasi sebenarnya, namun hanya sampai titik ujung jalan setapak menuju Sumber Towo. Sumber Towo terletak pada sebuah hutan kecil yang padat tanamannya, sehingga signal agak susah diperoleh disana. Susahnya signal di Sumber Towo menjadi salah satu penyebab lokasi Sumber Towo tidak dapat dideteksi dengan sempurna. Pihak pemerintahan desa akan menambahkan papan petunjuk menuju lokasi untuk tempat-tempat yang arahnya tidak dapat ditampilkan dengan sempurna oleh sistem. Secara keseluruhan aplikasi dapat membantu desa untuk mempromosikan wisata Selotapak. Melalui uji coba eksternal, aplikasi yang dibuat sudah sesuai dengan tujuan dibuatnya aplikasi tersebut. Wisatawan pengguna aplikasi ataupun pengelola wisata menyatakan terbantu dengan adanya aplikasi ini.

Berdasarkan hasil implementasi, uji coba internal dan eksternal dapat dikatakan bahwa aplikasi ini dapat digunakan dengan mudah oleh wisatawan untuk mengetahui wisata Selotapak dan mendapatkan lokasi, deskripsi, atau informasi lainnya. Terlihat bahwa lebih dari $80 \%$ responden setuju bahwa semua fitur dapat memudahkan untuk berwisata di Selotapak. Sistem ini juga bisa menampilkan arah dari posisi saat ini ke lokasi wisata yang dituju. Melalui fitur get direction, wisatawan dapat menuju lokasi wisata tanpa takut tersesat. Bahkan ada 
yang menyampaikan bahwa dengan fitur ini wisatawan tidak perlu menyewa pemandu wisata lagi.

Pada penelitian sebelumnya, Lengkong (2019), Duwitau (2020), Latifah (2021), telah membuat sistem informasi pariwisata dengan memanfaatkan teknologi website. Pada penelitian ini sistem informasi yang dibangun berbasis android. Beberapa fitur pada aplikasi masih mengadopsi dari penelitian sebelumnya, namun di Go-Selotapak pengguna dapat menggunakan fitur get direction, yaitu fitur yang dapat menampilkan rute dari posisi pengguna menuju lokasi wisata dengan Google MapAPI, sehingga pengguna tidak akan tersesat saat menuju lokasi wisata tertentu. Beberapa fitur yang terdapat di aplikasi Go-Selotapak namun tidak ada di tiga penelitian sebelumnya adalah fitur memberi rating di setiap lokasi wisata, sewa pemandu wisata, sewa kendaraan, dan mengunggah foto. Namun tidak semua foto yang diunggah pengguna akan tampil di aplikasi. Admin akan menvalidasi foto-foto yang bisa ditampilkan di aplikasi. Namun ada beberapa fitur wisatawan yang ada di penelitian sebelumnya dan tidak ada pada penelitian ini, misalkan pencarian lokasi wisata, melihat event terdekat kegiatan desa, ataupun akses untuk menambah/mengedit/menghapus berita terkait wisata di tempat tersebut. Pada aplikasi ini, pengguna wisatawan tidak harus mempunyai akun. Namun fitur yang tersedia berbeda untuk pengguna yang mempunyai akun dan tidak punya akun. Untuk fitur sewa dan unggah hanya bisa diakses untuk pengguna yang mempunyai akun. Tabel 3 menunjukkan fitur-fitur yang ada pada penelitian ini dan penelitian sebelumnya.

Tabel 3

Perbandingan Fitur Untuk Pengguna Umum

\begin{tabular}{|c|c|c|c|c|c|}
\hline \multirow[b]{2}{*}{ No } & \multirow[b]{2}{*}{ Fitur Wisatawan } & \multicolumn{4}{|c|}{ Peneliti } \\
\hline & & $\begin{array}{l}\text { Duwitau } \\
\text { (Website) }\end{array}$ & $\begin{array}{c}\text { Latifah } \\
\text { (Website) }\end{array}$ & $\begin{array}{l}\text { Lengkong } \\
\text { (Website) }\end{array}$ & $\begin{array}{c}\text { Penulis } \\
\text { (Android) }\end{array}$ \\
\hline 1. & Pencarian lokasi wisata & & $\mathrm{V}$ & & \\
\hline 2. & Melihat objek wisata & $\mathrm{v}$ & $\mathrm{v}$ & $\mathrm{v}$ & $\mathrm{v}$ \\
\hline 3. & Melihat data event & $\mathrm{v}$ & & & \\
\hline 4. & Melihat berita & $\checkmark$ & & $\begin{array}{c}\mathrm{V} \\
\text { (tambah/edit/hapus) }\end{array}$ & v \\
\hline 5. & Mencari rute & $v$ & & & $v$ \\
\hline 6. & $\begin{array}{l}\text { Mengirim pesan kontak } \\
\text { kami }\end{array}$ & $v$ & v & & v \\
\hline 7. & Melihat gallery & * & $\mathrm{v}$ & $\mathrm{v}$ & v \\
\hline 8. & Memberi Komentar & & $\mathrm{v}$ & & $\mathrm{v}$ \\
\hline 9. & Memberi rating & & & & $\checkmark$ \\
\hline 10. & Mengupload foto & & & & $\checkmark$ \\
\hline 11. & Sewa pemandu wisata & & & & $\checkmark$ \\
\hline 12. & Sewa kendaraan & & & & $\mathrm{v}$ \\
\hline 13. & Info akomodasi & & $\mathrm{v}$ & & \\
\hline
\end{tabular}

*Tidak ada fitur khusus gallery. Foto ditampilkan di objek wisata.

\section{SIMPULAN}

Aplikasi yang dibuat telah dapat menyelesaikan permasalahan pengelola wisata untuk menyebarkan informasi wisata di Selotapak. Berdasarkan uji coba eksternal kepada wisatawan yang datang ke Selotapak, lebih dari $80 \%$ responden menyatakan bahwa fitur-fitur pada aplikasi ini telah dapat membantu responden untuk mengetahui semua lokasi wisata dan arah menuju lokasi tersebut. Aplikasi juga mudah digunakan sehingga responden tidak kesulitan untuk menggunakan fitur-fitur di aplikasi. 


\section{PUSTAKA ACUAN}

Asmawati, E, Herlambang, A., Andajani, E., Sutowijoyo, H 2020,'Desain Desa Wisata Selotapak Kecamatan Trawas Berbasis Pemberdayaan Masyarakat Dan Potensi Alam', Prosiding Semadif, hal 30-38.

Duwitau, F, Wijanarko, R 2020,' Sistem Informasi Pariwisata Daerah Kabupaten Nabire Berbasis Web', Jurnal Informatika dan Rekayasa Perangkat Lunak, Vol 2, No 2.

Latifah, K \& Mukaroh, EN 2021, 'Rancang Bangun Sistem Informasi Pariwisata Berbasis Web Sebagai Media Promosi Pada Kabupaten Lampung Barat', Cyberarea.id Volume 1 (3).

Lengkong, CM, Sengkey, R, Sugiarso, BA 2019, 'Sistem Informasi Pariwisata Berbasis Web di Kabupaten Minahasa', Jurnal Teknik Informatika, Vol 14, No 1.

Musdar, IA \& Arfandy, H 2020, 'Rancang Bangun Sistem Informasi Pariwisata Sulawesi Selatan Berbasis Android Dengan Menggunakan Metode Prototyping', SINTECH JOURNAL, ISSN 2598-7305, Vol. 3 No 1 - April. 